\title{
'Bridging the Gap' between EU Politics and Citizens? The European Commission, National Media and EU Affairs in the Public Sphere
}

Citation for published version (APA):

Bijsmans, P. H. M. G., \& Altides, C. (2007). 'Bridging the Gap' between EU Politics and Citizens? The European Commission, National Media and EU Affairs in the Public Sphere. Journal of European Integration, 29, 323-340. https://doi.org/10.1080/07036330701442315

Document status and date:

Published: 01/01/2007

DOI:

10.1080/07036330701442315

Document Version:

Publisher's PDF, also known as Version of record

\section{Document license:}

Taverne

Please check the document version of this publication:

- A submitted manuscript is the version of the article upon submission and before peer-review. There can be important differences between the submitted version and the official published version of record.

People interested in the research are advised to contact the author for the final version of the publication, or visit the DOI to the publisher's website.

- The final author version and the galley proof are versions of the publication after peer review.

- The final published version features the final layout of the paper including the volume, issue and page numbers.

Link to publication

\footnotetext{
General rights rights.

- You may freely distribute the URL identifying the publication in the public portal. please follow below link for the End User Agreement:

www.umlib.nl/taverne-license

Take down policy

If you believe that this document breaches copyright please contact us at:

repository@maastrichtuniversity.nl

providing details and we will investigate your claim.
}

Copyright and moral rights for the publications made accessible in the public portal are retained by the authors and/or other copyright owners and it is a condition of accessing publications that users recognise and abide by the legal requirements associated with these

- Users may download and print one copy of any publication from the public portal for the purpose of private study or research.

- You may not further distribute the material or use it for any profit-making activity or commercial gain

If the publication is distributed under the terms of Article $25 \mathrm{fa}$ of the Dutch Copyright Act, indicated by the "Taverne" license above, 


\section{'Bridging the Gap' between EU Politics and Citizens? The European Commission, National Media and EU Affairs in the Public Sphere}

\section{Patrick Bijsmans \& Christina Altides}

To cite this article: Patrick Bijsmans \& Christina Altides (2007) 'Bridging the Gap' between EU Politics and Citizens? The European Commission, National Media and EU Affairs in the Public Sphere, European Integration, 29:3, 323-340, DOI: 10.1080/07036330701442315

To link to this article: https://doi.org/10.1080/07036330701442315

曲 Published online: 04 Dec 2007.

Submit your article to this journal 전

III Article views: 3732

Q View related articles ¿

4 Citing articles: 7 View citing articles 준 


\title{
'Bridging the Gap' between EU Politics and Citizens? The European Commission, National Media and EU Affairs in the Public Sphere
}

\author{
PATRICK BIJSMANS* \& CHRISTINA ALTIDES** \\ "Department of Political Science, Maastricht University, Maastricht, The Netherlands \\ *"Mannheim Centre for European Social Research (MZES), Mannheim University, \\ Mannheim, Germany
}

\begin{abstract}
Information about political processes is an important prerequisite for debates in the public sphere, which can strengthen the legitimacy of decisions. This article analyses how far both Commission communication and media news coverage contain information on (a) policy issues, (b) the policy process and (c) the actors involved and the positions they take. Data have been gathered through a qualitative content analysis of Commission communication output and the news coverage in two Dutch and two German newspapers with regard to two specific policies: the sustainable use of natural resources and wastes and the accession process leading up to the Eastern Enlargement. The results suggest that the Commission and the national media emphasize different aspects of the EU political process. This could pose problems in terms of the legitimacy of EU policies and the Commission's role therein.
\end{abstract}

KEY WORDS: Democracy, political communication, European Commission, media, public sphere

\section{Introduction}

The democratic legitimacy of a political system and its policies depends on the interaction between citizens and political actors. A key provision in this respect is the "stability of communication between represented and

Correspondence Address: Patrick Bijsmans, Department of Political Science, Faculty of Arts and Social Sciences, Maastricht University, PO Box 616, 6200 MD Maastricht, The Netherlands.Email: patrick.bijsmans@politics.unimaas.nl 
representatives" (Benz \& Papadopoulos 2006, 6), which mainly evolves in the public sphere. Citizens should have the opportunity to discuss political affairs and voice their opinion, for which they need to acquire what Dahl (1989, 111-112) has called an "enlightened understanding" of public matters. This is possible only when information about the political process is made available in the public arena (McNair 2003, 18-19). Here, citizens rely mainly on the media, who connect represented and representatives. Thus, information is typically made available by both political actors and the media.

With regard to the EU, the above poses a problem since this polity displays a public deficit: European affairs receive only moderate attention in the public sphere (e.g. Kantner 2003). Multi-level deliberative processes can take place only when political institutions and the media at local, regional, national and supranational level inform citizens comprehensively about policy facts and political targets (Gramberger 1997, 78). In the past, neither the European institutions nor the national media seemed to fulfil this prerequisite, but since the Maastricht Treaty EU policy making has gained importance and EU politics have become more salient and contested. From the perspective of democratic legitimacy, the increase of the Union's impact on public policy requires a more regular discussion in the public sphere.

Forced by negative opinion surveys and referendum outcomes since the early 1990s, it was the Commission, in particular, that started to redefine its media-relations and communication policy. Until recently it invested only little time in communicating its activities to the world outside Brussels (Gramberger 1997; Meyer 1999). Its attitude towards public communication was rather ambiguous, varying "between half hearted reform attempts, political neglect and outright hostility" (Meyer 1999, 624). In the last five years, however, the Commission has drafted an ambitious Communication Strategy with a concrete Action Plan (Commission of the European Communities 2002; 2005), appointed a Commissioner for Communication and Institutional Relations and restructured its organization. In the beginning of 2006 it also launched a White Paper on Communication (Commission of the European Communities 2006). 'Bridging the gap' between EU politics and citizens has advanced as a core catchphrase in this evolution.

Initially, the media did not consider European politics as particularly salient. There were only a handful of predominantly benign and even idealistic Brussels-based journalists. Today, EU affairs are increasingly regarded as having a decisive impact on national politics. One can observe an evergrowing body of - ever more critical - journalists being based in Brussels (Baisnée 2004). Still, EU affairs are included only rarely in national news, due to their highly technical nature and seeming detachedness from the national political process. The coverage is not always positive nor has its quantity increased substantially (Gerhards 2000) - but European politics have certainly become more scrutinized.

Irrespective of quantity and change over time, what can one say about today's substance of Commission communication on and media coverage of Commission-related EU affairs? In other words, do Commission and media 
offer comprehensive information about policy facts and political targets in the cases they do engage in communication? Little is known about what EU institutions communicate and how this is reflected in media coverage (cf. Gleissner \& De Vreese 2005, 222). This article attempts to shed more light on this issue. It will set out to answer the following question: To what extent do European Commission communication and its coverage by the national media provide the information required for the discussion of EU affairs in the public sphere?

\section{The 'EU Political Communication Playing Ground'}

At the national level political communication is constituted through national governments, parliaments, organized interests and other political actors which engage in public political discourses via the mass media. Press releases, press conferences and mediated events are only some of the communication instruments used in this context. Political actors increasingly put efforts into professionalizing their communications and complying as much as possible with the news values that shape the media's attention for political affairs (Street 2001; McNair 2003).

At the European level, political communication by EU actors is much more complicated. There is no 'real' European government and the division of competences is blurred, which often impedes the clear attribution of political responsibility and accountability in EU politics (Lord 1998). This enables national governments and other political actors to occasionally use the EU in general and the Commission's image or its decisions in particular to shift the blame for unpopular decisions. As the national parliaments and publics are often unaware of what takes place during the negotiating process, opportunities are ample to do so (Smith 2000).

The Commission, while often publicly perceived as being the 'European government', does not have any substantial decision-making powers nor is it accountable to the European citizens in the traditional sense; as an elected body. But being the core EU policy initiator and implementation watchdog, the Commission might seek public support to push forward its own proposals and to be able to implement EU legislation more smoothly. If it wants to enhance its public legitimacy and escape the 'blame game', it is worthwhile to communicate what it is responsible (or not responsible) for. Furthermore, the Commission at times pursues a more political - in opposition to a mere administrative - role (Lord 1998, 82; Christiansen 2006, 100ff.) and some of its responsibilities (for example, the monitoring of member states' compliance to EU law) do encourage it to take a more outright position. Hence, it needs to gather support for its activities.

From the perspective of democratic legitimacy, the media are expected to scrutinize political processes from the very beginning and enable public debate on sensitive political issues before the actual decisions are taken. This can generate the occasion for an inclusive, multi-level deliberative process, offering the European citizenry opportunities to engage in debates and hold accountable their representatives in the EU political arena (Auberger \& 
Iszkowski, this issue). One important problem in this respect is the absence of a homogeneous European public. The political actors in the EU polity need to address twenty-seven national publics. As there are no widely used pan-European media (Schlesinger 1999; McQuail 2001, 218-220) they depend on a broad range of national media to do so. In fact, as Vink (this issue, 317) explains, "it seems natural to build on structures already available and see how they can provide the communication infrastructure". The national media may, however, focus on issues of domestic interest which do not necessarily coincide with European affairs.

The EU institutions - most notably the European Parliament (EP) and the Commission - are generally regarded as being more open than national institutions and governments (Morgan 1995, 325; Baisnée 2004, 137). As a result, they have been important sources of information for Brussels-based correspondents. Still, journalists are often negative about the European institutions' communication efforts (Gleissner \& De Vreese 2005, 227). The content of Commission communication does not always comply with news values. On the one hand, this reflects the classical conflict between media logic and political logic. Wary, highly complex and long negotiation and decision-making procedures do not necessarily meet media attention criteria, such as actuality, immediateness or conflict (Pfetsch 1996; cf. Street 2001). On the other hand, EU affairs are seen as being particularly dull due to the tendency to play down differences and strive for consensus (Semetko et al. 2000, 130; Kevin 2003, 122-124, 127). Furthermore, EU affairs are considered salient by the media only when their impact on national affairs is evident (cf. Gleissner \& De Vreese 2005, 228).

Over the years, a multitude of other sources have come to have an impact on media attention, including regional representatives, interest groups and fellow reporters (Morgan 1995, 328). For journalists this new situation offers the possibility of exploring different viewpoints, but it might restrain the effectiveness of Commission communication.

\section{Dimensions of Political Communication}

The factors and processes introduced above have to be kept in mind when analysing Commission and media communication content, but which requirements does political communication have to fulfil in the context of democratic legitimacy? For sure, information and the means to communicate need to be widely accessible. Besides this formal criterion, the content of mediated debates and the availability of information on different aspects of the political process are of particular importance (Negrine 1996, 21). In this respect, Meyer (1999) has developed a useful instrument for the analysis of qualitative aspects of communication, based on broader theoretical considerations. He distinguished between three content-related dimensions that should be present in political communication:

1. The issue dimension: This information is a prerequisite for informed public debate and the possibility of feedback into decision-making. 
2. The procedural dimension: The communication of decision-making procedures can help to make politics visible and accessible to the public.

3. The accountability dimension: Without this information there can be no personal accountability vis-à-vis the public (Meyer 1999, 622ff.).

These three dimensions connect to the fact that accountability in the European polity should refer to "concrete procedures and processes" to enable an interaction between the European publics and the institutions that are involved in the policy making process (Vink, this issue, 318). The communication of these three dimensions does not automatically imply a direct impact on public debate or the EU's democratic legitimacy. It can, however, be seen as complementing institutional traits designed to secure democratic values such as accountability, responsiveness, transparency and political participation (Holzhacker, this issue). In other words, political communication alone is not sufficient to enhance democratic legitimacy, but it is a necessary element of a democratic political process. ${ }^{1}$

Table 1. Three content dimensions

Dimension
Qualitative indicators
Policy explanation
How far are political actions and issues involved explained in both
Commission and media communication output?
What does the text say about ...
(a) $\ldots$ the present or prior situation, the background of the policy/
(b) $\ldots$ the aims the Commission pursues with its action and why?
(c) $\ldots$ how those aims and objectives are to be achieved?
(d) $\ldots$ the relevance of the policy for citizens?

Procedural

How far do the texts clarify the decision-making process and the information current stage of it?

What does the text say about ...

(a) ... actual steps in the policy making process at the moment?

(b) ... past steps in the policy making process?

(c) ... future steps in the policy- and decision-making process?

Information on How far do the texts clarify who in the Commission is responsible for responsibilities the action in question and how other actors are involved in the decision-making process?

What does the text say about ...
(a) ... who in the Commission is responsible for the action?
(b) ... the involvement of other actors in the policy making process?
(c) ... the political responsibilities, positions or actions of other actors in the issue? 
Meyer's approach shall form the basis for the empirical analysis. To make his three dimensions compatible to the European polity and more specifically to political communication at the EU level, they have been adapted (Table 1).

Political and media actors will, of course, not always refer to all three above-mentioned dimensions in their communication efforts. This is true for the European and the national level. Still, the three dimensions will enable us to analytically structure and compare the political substance of Commission communication output and media coverage. This will yield some tentative indications on the ability of the Commission to address European citizens via the media, as well as on the information journalists are particularly interested in.

\section{Data Gathering, Case Selection and Case studies}

Since the popular resonance of the supranational European public sphere is virtually absent, it is generally thought that national public spheres are essential for stimulating public debates on EU affairs (e.g. Schlesinger 1999; Voltmer \& Eilders 2003). As Vink (this issue) asserts, varying democratic structures at all levels need to be strengthened, which would ultimately also hold for the different public spheres. Therefore, this article addresses the communication of Union politics in national public spheres. The findings are based on a qualitative content analysis of media and Commission output in $2003,{ }^{2}$ concerning one case study involving an issue important to the media, and another one on a priority topic for the Commission. The analysis will enable us to draw an exemplary picture of the communication of EU affairs in the public sphere.

\section{Data Gathering}

The study of media content is based upon the analysis of newspaper articles in Germany and the Netherlands. These countries have been part of the European integration process from the early days and have displayed comparable attitudes towards this process. ${ }^{3}$ In addition, the infrastructures for public debates in Germany and the Netherlands are very similar. Hence, it is possible to discuss political communication on EU affairs in analogous contexts. With regard to Germany, the study has opted for the Frankfurter Allgemeine Zeitung (FAZ) and the Süddeutsche Zeitung (SZ); the selected Dutch newspapers are NRC Handelsblad (NRC) and de Volkskrant (VK). These elite newspapers play a prominent role as agenda-setters for other media as well as for political actors (Kaase 2000, 376; Pauw Sanders Zeilstra Van Spaendonck 2004). Moreover, newspapers offer the most detailed overview of issues covered by the media, as they are able to provide background information and analysis.

The study of Commission output is based upon the analysis of press releases. Press releases are one of the main instruments to reach the media, available in hard copy, on the website or as a daily Midday Express Newsletter to all subscribers. They are also often presented in the institutionalized 
daily midday briefings or in special press briefings. Press releases are not the only information source for journalists, but they are amongst the most regular and formalized information sources available to everyone. ${ }^{4}$ According to research on national political communication, journalists are likely to resort to press releases when under time pressure. Hence, press releases follow journalistic logic by supplying news that is practically ready-made (McNair 2003, 71). The media might either resort to the original press release or receive a processed version through press agencies. Even if press releases are not cited directly, they can influence the media's news agenda. They are therefore considered an essential communication tool by the Commission - and a suitable information source to be analysed and compared with press articles.

\section{Case Selection}

On the basis of an initial scan of press releases and front-page newspaper articles, two policy areas have been selected: EU Environmental policy and Enlargement (Table 2). The first topic was prominent in Commission press releases, but hardly an issue in the newspaper front page articles. ${ }^{5}$ The second topic featured prominently in all four newspapers but not so much in the Commission press releases. Environmental policy is a rather technical field, whereas Enlargement is the domain of high politics. In both fields the Commission plays a major role. Also, both affect the lives of European citizens and it might therefore be argued that they should be subject to public

Table 2. Issue priorities in Commission press releases and newspaper front page articles in 2003

\begin{tabular}{|c|c|c|c|c|}
\hline Rank & $\begin{array}{l}\text { Commission } \\
\text { topics }\end{array}$ & $\begin{array}{l}\text { Press } \\
\text { releases }^{\mathrm{a}}\end{array}$ & Media topics & $\begin{array}{l}\text { Front pages } \\
\text { press articles }\end{array}$ \\
\hline 1 & Competition & $383(18.7)$ & Institutional matters & $211(26.6)$ \\
\hline 2 & External relations & $223(10.9)$ & External relations & $120(15.1)$ \\
\hline 3 & $\begin{array}{l}\text { Monetary policy } \\
\text { and economic } \\
\text { growth }\end{array}$ & $141(6.9)$ & Enlargement & $119(15.0)$ \\
\hline 4 & $\begin{array}{l}\text { Institutional } \\
\text { matters }\end{array}$ & $124(6.0)$ & $\begin{array}{l}\text { Monetary policy and } \\
\text { economic growth }\end{array}$ & $117(14.7)$ \\
\hline 5 & $\begin{array}{l}\text { Environmental } \\
\text { policy }\end{array}$ & $109(5.3)$ & Internal market & $34(4.3)$ \\
\hline$\overline{12}$ & Social policy & $81(3.9)$ & Social policy & $14(1.8)$ \\
\hline 13 & Enlargement & $80(3.9)$ & Health policy & $12(1.5)$ \\
\hline 14 & $\begin{array}{l}\text { Transport and } \\
\text { energy }\end{array}$ & $78(3.8)$ & $\begin{array}{l}\text { Environmental } \\
\text { policy }\end{array}$ & $11(1.4)$ \\
\hline Total number & & 2,053 & & 794 \\
\hline
\end{tabular}

${ }^{a}$ Numbers in parentheses are percentages 
debates. The juxtaposition of two priority topics allows examination of how far communication patterns depend on the nature of the issues.

Within the two selected policy areas, the focus was narrowed down even further to the accession process leading up to the Eastern Enlargement and to all policies related to the sustainable use of natural resources and wastes, again following the principle of the number of front page articles in the case of Enlargement and the number of press releases in the case of Environmental Policy. Then, articles from all the pages in the four selected newspapers in 2003 regarding those two policy areas were gathered. Together with the press releases found earlier, this constituted the main material for analysis to answer the research question.

\section{The Case Studies}

Environmental policy making dates back to the late 1950s and early 1960s, but has only been part of the acquis since the Single European Act of 1986. The Commission has the exclusive right of initiative and is in charge of policy implementation. Sustainability has become one of the key issues of environmental policy (McCormick 2001, 76-77). The Sixth Environmental Action Programme (2002-2012) has identified the sustainable use of natural resources and waste as one of the key areas. ${ }^{6}$ This is reflected in the fact that most Commission press releases on environmental policy in 2003 deal with the sustainable use of natural resources and waste. In the media none of the front page articles on EU environmental policy in 2003 was related to this issue. Yet, while the topic has not been prominent in the press' front pages articles, fifty-seven articles were eligible for analysis in the inner pages of the newspapers.

The Eastern Enlargement was the most significant in size and impact, embracing ten former communist countries - Bulgaria, Czech Republic, Estonia, Hungary, Latvia, Lithuania, Poland, Romania, Slovakia and Slovenia - and Cyprus and Malta. The Commission played a key role in the shaping of the EU's policy towards post-Cold War Eastern Europe and in the accession process. It issued opinions on the prospects of the candidates, produced progress reports and acted as the main negotiator on behalf of the EU. Its recommendations play a key role in the decision-making process (Avery 2004, 39-40). While being one of the most prominent topics in the four newspapers, Enlargement was not particularly exposed in the Commission press releases in 2003 (Table 2). But both the newspapers (ninety-five articles) and the press releases (forty) paid particular attention to the accession negotiation process.

\section{Empirical Results}

Regarding environmental sustainability, the press releases focused on the Commission issuing studies, presenting strategies, proposing directives and pursuing infringement procedures, particularly in the fields of waste management, hydrogen and fuel cells, and energy saving. Only a few press 
releases dealt with other institutions' activities or decisions, mainly with regard to EP and Council agreements on the Directive on Packaging and Packaging Waste (2 July 2003 and 8 December 2003). In the case of Enlargement, the Commission published opinions, monitoring or progress reports. It also announced the opening of negotiations, meetings and agreements and issued warnings to ensure that the Copenhagen criteria are met by all candidates by the time of accession. Also, in many press releases Commission President Prodi and Enlargement Commissioner Verheugen commented on the referenda held by most candidate countries in 2003.

In the press articles, those activities and subjects were reflected only partly. Generally, the Dutch and the German newspapers displayed the same kind of coverage, despite some small differences in the number of articles and some of the issues that were covered. In the sustainability case, prevailing press article topics resembled the Commission focus considerably. Newspapers were thus mainly concerned with EU activities in the fields of saving energy (combined with research on renewable energies), fostering hydrogen and fossil fuels and waste management (including a few references to decisions regarding the Packaging and Packaging Waste Directive). However, while the Commission put an emphasis on policy initiation, it was the national implementation of EU legislation that was central to all newspapers. This explains why the directive on the reuse and recycling of Waste Electrical and Electronic Equipment (the WEEE directive) decided in 2002, was discussed prominently in the media although it was no longer an issue in the 2003 press releases.

In the case of the accession process, core issues in the press coverage included the accession referenda in the candidate countries and their progress in the transposition and implementation of EU laws and requirements. They were therefore also comparable to Commission concerns, though the articles did not always mention the Commission as a (central) actor, as the press releases did. The most prominent example in which the institution was presented as such in the press, was around the time the Commission issued its report on the candidates' progress towards accession. Here, were found press articles anticipating the report, covering its publication on 5 November and referring to it in subsequent articles on the accession process. Table 3 provides a more detailed overview of the results of both case studies following the analytical dimensions introduced above.

The Commission press releases displayed no major differences between the communication of both subjects. There was no particular focus in any of them, subjects were treated with the same intensity and the content patterns were largely compatible (except for some more procedural information in the Enlargement case). The analysis of the four newspapers shows different traits: the subject that was of particular interest on the front pages from 2003 - the accession process - also gained most attention, not only in terms of quantity but also in terms of substance. Two main differences should be noted.

First, while in both case studies the press releases described the Commission as being actively involved in EU policy making - for example by 
Table 3. Comparing the results

\begin{tabular}{|c|c|c|}
\hline & Sustainability & Accession process \\
\hline $\begin{array}{l}\text { Policy } \\
\text { explanation }\end{array}$ & $\begin{array}{l}\text { - Detailed policy background by both } \\
\text { the European Commission (EC) and } \\
\text { media; } \\
\text { - Active versus passive EC involvement } \\
\text { in press releases versus media; } \\
\text { - EC more on reasons/aims and } \\
\text { measures, significantly more on } \\
\text { citizens' relevance }\end{array}$ & $\begin{array}{l}\text { - Detailed policy background by } \\
\text { both EC and media; } \\
\text { - Active EC involvement in press } \\
\text { releases and media; } \\
\text { - EC more on reasons/aims and } \\
\text { measures, significantly more on } \\
\text { citizens' relevance }\end{array}$ \\
\hline $\begin{array}{l}\text { Procedural } \\
\text { information }\end{array}$ & $\begin{array}{l}\text { - Commission and media focus on } \\
\text { present policy steps but also } \\
\text { considerable information on future } \\
\text { and past steps; } \\
\text { - Media less on future and past than EC; }\end{array}$ & $\begin{array}{l}\text { - Rather equal treatment by EC } \\
\text { versus present and future } \\
\text { preference for media; } \\
\text { - Qualitative difference between } \\
\text { EC and media future references; }\end{array}$ \\
\hline $\begin{array}{l}\text { Information } \\
\text { on } \\
\text { responsibilities }\end{array}$ & $\begin{array}{l}\text { - Personalization versus EC as an } \\
\text { "obscure authority"; } \\
\text { - Qualitative difference between EC and } \\
\text { media when mentioning other actors } \\
\text { involved }\end{array}$ & $\begin{array}{l}\text { - High personalization on both } \\
\text { sides (even if not } 100 \%) \text {; } \\
\text { - Qualitative difference between } \\
\text { EC and media when mentioning } \\
\text { other actors involved }\end{array}$ \\
\hline
\end{tabular}

presenting the institution's roles and responsibilities - this is not reflected equally in the press coverage of the two case studies. In the Enlargement case, the Commission and individual Commission officials ${ }^{7}$ are portrayed in a rather prominent and active role. They critically monitor the progress made by the candidate countries and issue reports, warnings and public criticism concerning their shortcomings. They also comment on the outcomes of the referenda. In the sustainability case, however, the Commission is often reported as only an additional player in the political game and, hence, is broadly deprived of a political responsibility or an own position. Furthermore, in the large majority of articles, the Commission is even mentioned only implicitly, for example when referring to 'Brussels', 'EU legislation' or projects funded 'by the EU'.

Secondly, both the press releases and the newspaper articles are much more precise with regard to the Commission's responsibilities in the policy process in the accession negotiations than they are in sustainable environmental policies. In both fields, the institution oversees implementation. This, however, was not clear from the press coverage on sustainability. The Commission's watchdog role was more apparent in the reporting on the accession process.

It might be argued that these important differences in media coverage between the two case studies confirm the theoretical expectations sketched out in the presentation of the case studies. Namely, that the "history-making decision" (Peterson \& Bomberg 1999) to enlarge the EU would receive more attention in the European public sphere than the rather technocratic issue of 
the sustainable use of natural resources and waste. What is interesting, though, is that the comparison of Commission communication to media coverage in both case studies shows even more similar characteristics.

To start with, both the Commission press releases and the newspaper articles provided a detailed policy background to the issues. However, overall, the press releases provided a much broader picture with regard to the policy process, focusing on past, present and future steps. The media's focus was more concerned with current stages. Although sometimes upcoming developments were also referred to (especially with regard to the accession process), the references to policy steps in the press were qualitatively different from those of the Commission. The Commission did not refrain from providing rather detailed procedural information, such as the EP's decision on the Enlargement go-ahead being planned to be taken on 9 April, the Council decision following on 14 April, and the signing of the treaty of accession on 16 April (19 February 2003); or that the expenditure programmes would be starting on 1 January 2004 (26 June 2003) if the appropriate legislation is transposed by 31 December 2003 (16 July 2003). Despite references to current steps in the accession process, such as the EP's decision (NRC and SZ 10 April 2003), news articles were often very implicit about what was to happen next. In fact, statements such as "Poland will join the EU next year" and "accession will commence in 2004" were abundant.

In the media, the aims of initiatives, proposals, etc., were often not mentioned at all or only implicitly. In the sustainability case, for example, there were a number of articles sketching out an actual situation with a bad impact on the environment (for example, "millions of old mobile phones are thrown away and thus polluting the environment as they contain hazardous substances", SZ 27 December 2003). This situation would change as EU legislation would enter into force and would have to be implemented. Furthermore, the range of possible Commission operations differed considerably between press releases and press articles. Taking the press releases of the two case studies together, the Commission presented itself as proposing legislation, funding projects, issuing reports, opening infringement procedures, drafting strategy papers or action plans, launching competitions or organizing conferences. Yet, it was mainly the first three tasks that were reported in the media. Moreover, press coverage of concrete measures proposed by the Commission to tackle particular problems was dominated by references to system regulation and quota or target setting. Other (rather market-based) approaches such as labelling schemes, partnerships, or voluntary agreements were rarely mentioned. Finally, in the Enlargement case press releases tended to refer to aims and measures more regularly than in the sustainability case. On the other hand, if both were mentioned in the latter case, given information was more substantial than in the former one. ${ }^{8}$

In a similar pattern, the press releases regularly emphasized the importance of policy (initiatives) for citizens, which in both case studies was reflected only poorly in the media. Some issues that would seem very close to citizens' lives did not appear at all in the press coverage. This was, for example, the case with the Commission's efforts to help consumers identify the most 


\section{Patrick Bijsmans \& Christina Altides}

energy efficient (household) electronic devices through a Europe-wide A+ and A++ labelling system (3 July 2003). Also, the Commission and the media appeared to have different understandings of what comprises the citizens' interest. The Commission tended to emphasize long-term benefits in the general interest. A proposed directive should thus "deliver long lasting and increasing energy savings for consumers to benefit from better products and an improved environment" (9 September 2003) and infringement procedures were pursued as there was "a serious danger for public health" (24 July 2003). The media, on the other hand, were rather interested in concrete financial benefits for every citizen. They mentioned EU legislation in the context of, for example, consumers not having to pay disposal costs for old cars (SZ 29 January 2003), electronic wastes (SZ 8 April 2003; VK 2 January 2003) or mobile phones (FAZ 9 July 2003) and reckoned that transparent electricity bills would lead to lower energy prices for consumers (SZ 27 December 2003; FAZ 5 June 2003). While both cases showed very low levels of explicit information on citizens' interests, in the Enlargement case, references were even less pronounced than in the sustainability case.

The only field in which press articles actually surpassed the Commission's information provision is the responsibility section concerning other actors involved in the process and their respective actions or positions. Though the Commission press releases referred almost as often to other actors involved in the political process as the newspaper articles did, those references differed considerably in substance. Other actors mainly comprised other EU institutions, national governments and, at times, unspecified stakeholders. Those actors were merely addressed, monitored or consulted - without mentioning what their stances or recommendations were. Press articles named a larger variety of actors and it became much clearer how they were involved. For example, a NRC article (6 November 2003) on the reactions in the accession countries to the Commission's progress report referred to national government representatives, opposition leaders and even media in these countries. An article in the VK (25 September 2003) addressed the discussion in the Netherlands on how to reach EU bio-fuels targets, referring to the opinions of a number of stakeholders. Parliamentarians and citizens also appeared in the media coverage. In the media, almost all these actors had an active voice, commented (positively or negatively) on EU legislation or were concerned with the implementation of EU directives.

\section{Discussion}

How can these results be interpreted in view of the aforementioned characteristics of the EU political communication playing ground? Moreover, how can they be valued within the context of democratic legitimacy?

\section{The Tension between Political and Media Logic}

Concerning the differences between the case studies, the issue of newsworthiness seems to have been important in the coverage of both policies. The 
media are not interested in long, wary decision-making processes, as was illustrated by the sustainability case. This seems to be true both at the national and the EU level. Environment policy is characterized by gradual developments and torturous negotiations and hence is not very newsworthy. The Eastern Enlargement was a long process too, yet its newsworthiness in 2003 was much more apparent. The process was clearly drawing to an end: the accession treaty was signed with the first ten candidate countries in April 2003, most of them organized referenda and, in November, the Commission issued an important progress report. Newsworthiness seems not only to have had an impact on quantitative levels of attention but also on qualitative levels. Relevant political actors, their actions and political processes seem to have been more salient in the history-making decision than in the technical every-day policy.

This expected tension between political and media logic is also a prominent feature when analysing similarities between the case studies. The Commission appeared to follow communication patterns of political actors at the national level - its press releases were generally very detailed, mentioning aims, instruments and procedures - but this clearly was not always reflected in the media coverage. Particularly in the sustainability case, the Commission's focus on its own role of policy initiation and procedural information clearly countered the newspapers' interest in actual decision-making and the national implementation of EU legislation. This illustrates what other scholars have already suggested: that there is almost no public debate on EU affairs before the actual decision-making (e.g. Teschner 2000, 81; Wimmel 2005, 473). The initiation of policy is thus hardly an issue in the news whereas this is the phase in which the Commission is most clearly involved.

Another aspect related to the conflict of logics is that other political actors are incorporated very differently in Commission press releases and newspaper articles. In all but a few cases the newspapers offered a stage to various opinions and therefore live up to the normative criteria to allow different voices to act in the public sphere. While the media welcome a variety of communicators on EU affairs, the Commission appears to blend them out, possibly to convince the media of the importance of its own opinions and activities. The Commission furthermore wants to avoid being caught up in the game of politics and tries to keep its political role as a mediator. It therefore refrains from presenting conflicting positions or taking clear positions itself. This again is fatal for media coverage, as conflict is exactly what journalists are often looking for to give political stories an interesting and intelligible drive.

\section{EU Political Communication and Democratic Legitimacy}

The findings so far confirmed theoretical considerations and clearly reflect political communication mechanisms at the national level. A number of additional findings, however, point at political communication features which are rather EU-specific and raise questions with regard to its democratic legitimacy. 
As outlined above, citizens should be able to gain a good insight into the political process in order for an inclusive, multi-level deliberative process to evolve. The Commission communicates a number of proposals in future tense which might also be an indication that it seeks support for its proposals. But the media hardly report on them and are more interested in concrete decisions or even only in the implementation of EU legislation. While this, on the one hand, confirms the expectations with respect to the conflicting political and media logic (see above), on the other hand, it contradicts the democratic requirement for media to scrutinize politics from the very beginning. Once the stage of policy initiation is passed there are few opportunities left to change proposals in the EU policy cycle (Peterson \& Bomberg 1999, 21; cf. Holzhacker, this issue). Media logic appears to outweigh the democratic function to enable discussion and participation.

As to the mentioning of the Commission's political responsibilities, the institution itself shows considerable efforts to personalize politics (at least at Commissioner level) that are, however, reflected only partly by the media. The latter only to a certain extent attach actions to concrete persons in the Commission and do not necessarily explain the Commission's central role in both environmental policy and Enlargement. This could prove problematic as many people are unaware of the Commission's role in the EU - and in general about the way in which the EU is governed (cf. Sinnott 1997) which complicates the institution's attempts to prove its legitimacy and the legitimacy of its policies.

If the Commission is to escape the blame game, one would expect it to not only refer to its own but also to other EU political actors' responsibilities. This is hardly the case in the two case studies. In addition, the Commission's tendency to avoid getting tangled up in political issues contrasts with its efforts to increase its legitimacy and reach out to the European citizens. Various scholars have argued that the politicization of EU affairs is important for increasing visibility and stimulating debate (Lodge 1994; Magnette 2003). The Commission press releases are not contributing to this.

Last, but not least, while the background of policies in both cases is usually rather clear, the relevance of the respective policies to the citizen is hardly explained. This is, however, one of the issues that play a central role in debates about European integration: why does 'Brussels' issue certain legislation? The lack of respective information, particularly in the media coverage, could possibly be linked to the tendency to nationalize news coverage. The question is: do national media fail to extract the respective national relevance from EU-level communication, or does the Commission fail to communicate national interests instead of a common European interest??

\section{Questions for Further Research}

The two case studies illustrate that information on EU affairs does filter through to European citizens, although it is far from comprehensive. At least three issues need further research. First, a better insight into the interaction between European institutions and the media needs to be developed. It has 
been seen that some articles discuss issues before the publication of the formal press release and that some press releases appear to influence reporters whereas others do not. Also, while Commissioner Günther Verheugen hardly issued any press releases, he played a central role in the news coverage of the accession process. How can these findings be explained?

Secondly, this study addressed only two cases in a limited setting. It does not address variation over time, yet focusing on a particular period may not always yield generalizable inferences. Moreover, it would be interesting to find out whether the findings also apply to other history-making or day-today policy processes, as well as to other EU institutions such as the EP. It should furthermore be stressed that such cases should also be studied in other countries besides Germany and the Netherlands as well as in different media. This would provide more insights into whether the coverage of EU affairs is indeed similar across different member states and various media outlets, as has also been suggested in other studies (e.g. McQuail 2001, 223-225).

Thirdly, and lastly, communication is not a one-way stream, but also requires responsiveness and discursiveness (e.g. Beierwaltes 2002). In other words, a functioning European public sphere would involve citizens being aware of the communicated information and discussing EU affairs. Governments and other EU political actors would need to be responsive to the outcome of these discussions. These two elements of democratic political communication could not be addressed in the context of this study, but are vital for the democratic legitimacy of European public policies.

\section{Conclusion}

The EU is often accused of being only moderately democratic and scholars have argued recently that the public deficit plays an important role in this respect. This has been acknowledged at all levels: the European institutions have professionalized their communication machinery and they have repeatedly stressed their commitment to fostering a European public sphere. However, these efforts can be successful only when journalists and editors are willing to cover EU affairs. Studies on media coverage show that this is not always the case. This begs the question to what extent the European institutions are actually able to enter the news agenda. This article has tried to give a first insight into this issue by studying not only media output, but also Commission press releases. The results suggest that, irrespective of the exact nature of the issue, the Commission and the national media emphasize different aspects of the EU political process. Whereas the Commission is quite elaborate about its role in and the development of the policy process, the media reflect this information only partly. The lack of references to European citizens' interest in the media further complicates the Commission's attempts to prove its legitimacy and the legitimacy of its policies.

At a time when scepticism about the EU is rising and citizens demand a bigger say in the political process, and considering the Commission's pivotal role in initiating policy, the absence of a public debate has a negative impact on the democratic legitimacy of the Union as a whole. In fact, right now the 
EU seems to be largely devoid of an inclusive, multi-level deliberative framework and the latter's potential to stimulate information, transparency, participation and consultation (Holzhacker, this issue) is not yet fulfilled.

\section{Acknowledgement}

The authors would like to thank Tannelie Blom, Frank Schimmelfennig, Monika Mokre and the participants in the panel 'Media reporting and debating Europe' at the ECPR Graduate Conference 2006 for their constructive comments and feedback on earlier drafts of this article. Thanks also go to Jon Foster for looking over the text for language usage.

\section{Notes}

1. Commission communication allows the mass media to follow, understand and report political processes. Media communication allows the audience to follow, understand and discuss as well as other media to report on these processes.

2. The year 2003 was selected for three reasons: there was only one Commission in this year (no change, as for example in 2004), the year is recent enough to bear topics of actual relevance and, at the same time, distant enough in the past to be able to put communication activities and interaction into context.

3. Although generally positive about the integration process at the onset, since the 1990s Dutch and German citizens have become more critical about the EU's functioning and its democratic credentials.

4. In contrast to, for example, information sources based on confidential relationships between journalists and spokespersons or other Commission officials.

5. In fact, except for the large numbers of press releases issued on Competition and External Relations, there was no true focus in the Commission's press releases. Instead, all subjects were represented rather equally.

6. Decision No 1600/2002/EC of the European Parliament and of the Council of 22 July 2002 laying down the Sixth Community Environment Action Programme. OJ 2002, L242/1-15.

7. These included not only Commissioners, but also for example spokespersons (FAZ 19 January 2003; VK 12 March 2003) and Commission representatives in the accession countries (NRC 4 November 2003).

8. In the Enlargement case, for example, the Commission spoke about improving conditions for enterprises, promoting the development of transport and environmental infrastructure, fostering the creation of jobs, etc. through the Community Support Framework and different operational programmes (26 June - 22 September 2003). The media simply refer to "fostering innovation and development" of candidate countries' infrastructure through "EU subsidies" (SZ 23 October 2003) or to helping candidates setting up necessary offices through "Commission support" (VK 30 June 2003). In contrast, one example of the sustainability case elaborates rather concretely on the EC wanting "to slow down the increasing waste avalanche, recycle a larger proportion of the wastes and ensure a most environment-friendly disposal through the definition of collecting points, recycling quotas with deadlines, and guidelines for a Europe wide retrieval system" (FAZ 26 March 2003).

9. Of course, some have suggested that the national focus of most media does not allow for Europeanwide debates to take place and might even increase scepticism. Yet, we would rather agree with Voltmer \& Eilders $(2003,195)$ who argued that a national focus on EU affairs might actually make people more aware of European politics.

\section{References}

Auberger, Tobias \& Iszkowski, Krzysztof (2007) Democratic Theory and the European Union: Focusing on 'Interest' or 'Reason'?, Journal of European Integration, 29(3), pp. 271-284. 
Avery, G. (2004) The enlargement negotiations, in: F. Cameron (ed.) The Future of Europe. Integration and Enlargement, pp. 33-62 (London: Routledge).

Baisné, O. (2004) The politics of the Commission as an information source, in: A. Smith (ed.) Politics and the European Commission. Actors, Interdependence, Legitimacy, pp. 134-155 (London: Routledge).

Beierwaltes, A. (2002) Demokratie und Medien. Der Begriff der Öffentlichkeit und seine Bedeutung für die Demokratie in Europa (Baden-Baden: Nomos Verlagsgesellschaft, $2^{\text {nd }}$ edn).

Benz, A. \& Papadopoulos, Y. (2006) Introduction. Governance and democracy: concepts and key issues, in: A. Benz \& Y. Papadopoulos (eds.) Governance and Democracy. Comparing National, European and International Experiences, pp. 1-16 (London: Routledge).

Christiansen, T. (2006) The European Commission: the European executive between continuity and change, in: J. Richardson (ed.) European Union. Power and Policy Making, pp. 147-170 (Abingdon: Routledge, $3^{\text {rd }}$ edn).

Commission of the European Communities (2002) Communication from the Commission to the Council, the European Parliament, the Economic and Social Committee and the Committee of the Regions on an Information and Communication Strategy for the European Union, Brussels, COM (2002) 350 final.

Commission of the European Communities (2005) Communication to the Commission: Action Plan to Improve Communicating Europe by the Commission, Brussels, SEC (2005) 985 final.

Commission of the European Communities (2006) White Paper on a European Communication Policy, Brussels, COM (2006) 35 final.

Dahl, R.A. (1989) Democracy and its Critics (New Haven: Yale University Press).

Gerhards, J. (2000) Europäisierung von Ökonomie und Politik und die Trägheit der Entstehung einer europäischen Öffentlichkeit, in: M. Bach (ed.) Die Europäisierung nationaler Gesellschaften (Kölner Zeitschrift für Soziologie und Sozialpsychologie, Sonderheft 40), pp.277-305 (Wiesbaden: Westdeutscher Verlag).

Gleissner, M. \& De Vreese, C.H. (2005) News about the EU Constitution. Journalistic challenges and media portrayal of the European Union Constitution, Journalism: Theory, Practice and Criticism, 6(2), pp. 221-242.

Gramberger, M.R. (1997) Die Öffentlichkeitsarbeit der Europäischen Kommission 1952-1996. PR zur Legitimation von Integration? (Baden-Baden: Nomos).

Holzhacker, Ronald (2007) Democratic Legitimacy and the European Union, Journal of European Integration, 29(3), pp. 257-269.

Kaase, M. (2000) Germany: A society and a media system in transition, in: R. Gunther \& A. Mughan (eds) Democracy and the Media. A Comparative Perspective, pp. 375-401 (Oxford: Oxford University Press).

Kantner, C. (2003) Öffentliche politische Kommunikation in der EU. Eine hermeneutisch-pragmatische Perspektive, in: A. Klein et al. (eds) Bürgerschaft, Öffentlichkeit und Demokratie in Europa, pp. 213-229 (Opladen: Leske + Budrich).

Kevin, D. (2003) Europe in the Media. A Comparison of Reporting, Representation, and Rhetoric in National Media Systems in Europe (Mahwah,NJ: Lawrence Erlbaum Associates).

Lodge, J. (1994) Transparency and democratic legitimacy, Journal of Common Market Studies, 32(3), pp. 343-368.

Lord, C. (1998) Democracy in the European Union (Sheffield: Sheffield University Press).

Magnette, P. (2003) European governance and civic participation: beyond elitist citizenship?, Political Studies, 51(1), pp. 144-160.

McCormick, J. (2001) Environmental Policy in the European Union (Basingstoke: Palgrave).

McNair, B. (2003) An Introduction to Political Communication (London: Routledge, $3^{\text {rd }}$ edn).

McQuail, D. (2001) The media in Europe, in: M. Guibernau (ed.) Governing European Diversity, pp. 195-228 (London: SAGE Publications).

Meyer, C.O. (1999) Political legitimacy and the invisibility of politics: Exploring the European Union's communication deficit, Journal of Common Market Studies, 37(4), pp. 617-639.

Morgan, D. (1995) British media and the European Union. The Brussels news beat and its problems, European Journal of Communication, 10(3), pp. 321-343.

Negrine, R. (1996) The Communication of Politics (London: SAGE Publications).

Pauw Sanders Zeilstra Van Spaendonck. (2004) Waar halen ze het vandaan? Tweede-Kamervragen in het jaar 2003/2004 (Den Haag). 


\section{Patrick Bijsmans \& Christina Altides}

Peterson, J. \& Bomberg, E. (1999) Decision-Making in the European Union (Basingstoke: Macmillan).

Pfetsch, B. (1996) Strategische Kommunikation als Antwort auf die Probleme der Politikvermittlung, Gewerkschaftliche Monatshefte, 47(5), pp. 280-287.

Schlesinger, Ph. (1999) Changing spaces of political communication: the case of the European Union, Political Communication, 16(3), pp. 263-279.

Semetko, H.A., De Vreese, C. \& Peter, J. (2000) Europeanised politics - Europeanised media? European integration and political communication, West European Politics, 23(4), pp. 121-141.

Sinnott, R. (1997) European Public Opinion and the European Union. The Knowledge Gap (Barcelona: Institut de Ciències Polítiques i Socials).

Smith, M.P. (2000) 'The Commission made me do it': The European Commission as a strategic asset in domestic politics, in: N. Nugent (ed.) At the Heart of the Union. Studies of the European Commission, pp. 170-189 (Basingstoke: Macmillan, $2^{\text {nd }}$ edn).

Street, J. (2001) Mass Media, Politics and Democracy (Basingstoke: Palgrave).

Teschner, J. (2000) No longer Europe's Europhiles? Euroscepticism in Germany in the 1990s, Journal of European Integration, 22(1), pp. 59-86.

Vink, Edwin (2007) Multi-level Democracy: Deliberative or Agonistic? The Search for Appropriate Normative Standards, Journal of European Integration, 29(3), pp. 303-322.

Voltmer, K. \& Eilders, C. (2003). The media agenda: The marginalization and domestication of Europe, in: K.H.F. Dyson \& K.H. Goetz (eds) Germany, Europe and the Politics of Constraints, pp. 173-197 (Oxford: Oxford University Press).

Wimmel, A. (2005) Transnationale Diskurs in der europäischen Medienöffentlichkeit: Die Debatte zum EU-Beitritt der Türkei, Politische Vierteljahresschrift, 46(3), pp. 459-483. 